\title{
Waste Handling Practices and Values of University Student
}

\author{
By Bretel B. Dolipas * \\ Jennifer Lyn S. Ramos \\ Monica S. Alimondo \\ Carmelo Madinno ${ }^{+}$
}

\begin{abstract}
The study intended to determine the waste management practice of students in Benguet State University, Philippines. BSU students commonly generate vegetable wastes, papers/tissues and plastic wrappers in their households and always practice waste segregation by classifying their solid wastes and disposing them in the appropriate waste bins or containers in their households. The study also revealed that BSU students have similar household waste handling practices regardless of their sex and family origin. However, the lower level students practiced nonsegregation of household wastes compared to the higher level students. Also, waste segregation is practiced more by BSU students who are residing in the University dormitories compared to those who are residing in apartments/boarding houses. BSU students correctly segregated household wastes into biodegradable, recyclables and residuals and usually disposed of their household wastes through "pick up by trucks;" this was more frequently observed with female students. Also, low landers frequently disposed of their household wastes by placing all types of wastes in a compost pit as compared to the highlanders. Sophomore and freshmen students frequently practiced waste disposal by "pick up by trucks" and placing all types of wastes into a compost pit. The waste disposal practices of BSU students varied significantly according to their type of residence. BSU students always considered their environmental concern, compliance to a law or ordinance, personal image in the community, and usefulness of recycled waste in practicing waste segregation. The study recommended that BSU students be reminded to strictly comply with the waste segregation policy of the Local Government Unit (LGU) in their community and the University.
\end{abstract}

Keywords: Disposal, Home origin, Segregation, Student values, Waste handling

\section{Introduction}

Waste management is an integral concern of every community or institution. It is plausible that the purpose of waste management could be to promote cleanliness and orderliness in a community or institution; to conserve resources by using recyclable materials; and/or to preserve the environment in response to climate change being experienced worldwide. Waste management has great impact on the condition of the environment. In physics, one of the variables of state is temperature, which has great impact on the climate's condition. Gases generated from the decomposition of the residual waste affect the variables of state. Pollutions from unsegregated, unrecycled and other mismanagement of waste contribute to the quality or composition of air. Ideal gas law states that the

*Professor, Master of Arts in General Science Degree Program Coordinator, Mathematics-PhysicsStatistics Department, Benguet State University, Philippines.

${ }^{\dagger}$ Assistant Professor, Mathematics-Physics-Statistics Department, Benguet State University, Philippines.

Instructor, Mathematics-Physics-Statistics Department, Benguet State University, Philippines.

${ }^{+}$Instructor, Mathematics-Physics-Statistics Department, Benguet State University, Philippines. 
product of pressure and volume of a gas is directly proportional to the temperature of the gas. The higher the temperature, the higher is its effect on the pressure and volume of the gas. The physical property of the atmosphere, water and soil is greatly affected by the existence of pollution, especially from waste. The attention given to waste management is evident in the policies pertaining to proper segregation, collection, transport, storage, treatment and disposal of solid wastes in the different levels of government offices, communities or institutions. For instance, as a nationwide concern, the Republic Act (R.A.) No. 9003, otherwise known as the Ecological Solid Waste Management Program, provides the general state policies on adopting a systematic, comprehensive and ecologically solid waste management program. Also, the R.A. No. 7160, also known as the Local Government Code, designates the Local Government Units (LGU) responsible for implementing and enforcing the provisions of solid waste management within their respective jurisdictions. Pursuant to this Act, the LGU of La Trinidad established its local solid waste management program, which is known as the Ecological Solid Waste Management Program of La Trinidad, Benguet. As an academic institution, Benguet State University (BSU) has its own waste management program, which is known as BSU Eco-Waste Management Program (BSU-EWMP), to support the waste management program of the LGU of La Trinidad. This program was formally implemented in 2007 through the College of Arts and Sciences (CAS).

However, one could argue that the success of the implementation of the different policies on waste management is reliant on the individual compliance and practices of the citizens in a certain community or institution. That is, studying the waste management program of a certain community or institution could be one way of assessing the implementation of its waste management program for possible improvements in addressing the issues and concerns involving waste management. Thus, the study was conducted to investigate the perceptions and practices of BSU students in waste management to assess the implementation of the waste management program of the University; no such study has been conducted since the BSU-EWMP was implemented.

\section{Significance of the Study}

The purpose of the research is to provide information on how students manage waste in their residences, which could contribute to proper waste management at BSU and could help the administration in enhancing the proper waste management process of the university. Therefore, pollution from waste could be prevented.

\section{Literature Review}

Household waste classified under solid waste refers to any non-liquid waste that is created by an individual person, household, small business, or institution, such as a school or hospital. This type of waste is commonly called trash or garbage and includes everyday items, things that are broken, food that has spoiled, 
or simply any item a person no longer needs or wants. Household waste also included household garbage, leftovers of food and other wastage that include old house hold items such as papers, plastic waste in the form of kitchen equipment or any other products that are consumed during every day activities.

A survey conducted in a selected locale in Manila, Philippines showed that households generated an average of $3.2 \mathrm{~kg}$ of solid waste per day, or 0.50 $\mathrm{kg} / \mathrm{capita} / \mathrm{day}$. The types of wastes commonly generated are food/kitchen wastes, papers, plastic bottles, metals, and cans, boxes/cartons, glass bottles, cellophane/ plastics, and yard/garden wastes (Bernardo 2008). Kitchen wastes and plastics are also the common household wastes in other developing countries (Yoada et al. 2014, Ulta \& Ultra 2013). Types of waste generated depended on household size and income (Ulta \& Ultra 2013).

In terms of waste handling practices, Bernardo (2008) found that most households segregate their wastes into plastic bottles, glass bottles, and other waste (mixed wastes). They do not practice composting or burning of waste, though they rely on garbage collection by the government. However, some dump their garbage in non-designated pick-up points, usually on a corner of the street.

Waste separation is also done in households by separating them first into different types before they dispose of it in different garbage bags, which were collected by local governments on scheduled days. The items which they think can be recycled are not mixed with the rest of the garbage. However, those households who have adequate space in their yards normally throw waste in the backyard and remove plastics when the garbage is dry; these were the only items collected by the local government for disposal (Banga 2013).

However, in a study conducted by Yoada et al. (2014) in urban Accra, the respondents did not separate their waste; out of the 364 households, only 63 $(17.3 \%)$ separated their waste when storing it, while the remaining $301(82.7 \%)$ did not do any kind of solid waste separation. Similar results were also found among students. Most of the college students do not usually practice the 3Rs (reduce, reuse, recycle) of waste management (Ferrer 2015); most do not segregate solid wastes (Ehrampoush \& Moghadam 2005, and Amini \& Ramazani 2001, Mesgarof et al. 2001 as cited by Ehrampoush \& Moghadam 2005); nearly half have poor practices towards waste management (Arora \& Agarwal 2011); secondary school students possessed poor waste management practices (Ifegbesan 2009).

According to research conducted by Ferrer (2015), when students are grouped according to certain profile variables, students' reduction practices are dependent on their course, year level, and academic grade; the students' reuse practices are dependent on their course and year level; and the students' recycling practices are not dependent on any of the profile variables. Propensity for waste management practices differ by sex, class and age of students where female students have more positive waste management practices than their male counterparts (Ifegbesan 2009); older students in the secondary school do not practice proper waste management compared to younger students (Vivek et al. 2013); educational status, age and gender influence the solid waste management in secondary schools (Adeolu et al. 2014). But in terms of the type of family to which 
students belong, no difference in students' practice about waste management was found (Vivek et al. 2013).

Within waste disposal practices at Ogun State, Nigeria, the most common method of disposing waste in secondary schools is open burning and only a few people practice composting (Ifegbesan 2009). The prevailing practice in families from Karnataka, India is throwing household wastes outside their premises (Vivek et al. 2013). In urban Accra, most households use community bins or had waste picked up at their homes by private contractors, while others disposed of their waste in gutters, streets, holes and nearby bushes (Yoada et al. 2014).

The waste disposal habits of students can be traced to values, culture and indigenous knowledge inculcated in them at the family level (Daniel \& Ibok 2013). In Nigerian universities, 64\% confirmed the uncooperative attitude of students to disposing of waste at the designated local sites. Many of them lacked education and training. Wastes are often dumped indiscriminately on open plots of land and particularly on streets. This method is based on "throw away culture" in which wastes are disposed of in the nearest open space, on land or surface water without environmental consideration. This is referred to as "not in my backyard syndrome," whereby the waste is merely transferred from one location to another location where its nuisance value is perceived to be less. Sometimes, wastes are buried or placed in a landfill with the hope that out of sight is out of mind (Opala, 1977, as cited by Daniel \& Ibok 2013). On the other hand, solid waste management practices of households were usually related to what they were accustomed to, hence depended on practices found within the households waste segregation, recycling, and encouragement of family members to do Solid Waste Management SWM (Macawili 2009).

\section{Conceptual Framework}

The independent variables are the household waste handling practice, household waste disposal practice, sex or gender, year level, type of residence and family origin. Of the independent variables, the level of handling practice of household waste and level of waste disposal practice; the comparison of the level of handling practice of household wastes when students are grouped according to sex, year level, type of residence and family origin; comparison of the level of waste disposal practice when students are grouped according to sex, year level, type of residence and family origin; and comparison of the students' observed values contributing to their waste management practice when they are grouped according to sex, year level, type of residence and family origin are to be measured. These are the dependent variables of the study (Figure 1). 
Figure 1. Paradigm of Study

Independent Variables

\begin{tabular}{|l|l|l|}
\hline Household waste \\
Handling practice \\
Household waste
\end{tabular}

\section{Objectives of the Study}

The research intended to determine the waste management practices that students had. It specifically determined the following:

1. What type of household wastes was usually found in students' household?

2. What were the handling practices of household wastes of students?

3. How were household wastes segregated in students' household?

4. How were household wastes disposed of in students' household?

5. What were the observed values contributing to the students' waste management practices?

\section{Hypotheses of the Study}

1. Students have an average level of handling practices regarding household waste.

2. Students have an average level of waste disposal practices.

3. There is a significant difference in the level of handling practices on household wastes when students are grouped according to:
a. $\operatorname{sex}$
b. year level
c. type of residence
d. family origin

4. There is a significant difference in the level of household waste disposal practices when students are grouped according to:

a. $\operatorname{sex}$

b. year level

c. type of residence

d. family origin 
5. There is a significant difference in the students' observed values contributing to their waste management practices when grouped according to:

a. sex

b. year level

c. type of residence

d. family origin

\section{Methodology}

\section{Locale of the Study}

This research was conducted during the second semester of the school year 2015-2016 at Benguet State University La Trinidad campus.

\section{Respondents}

The respondents were five hundred eleven (511) selected first year to fourth year undergraduate students from the different colleges and institutes of the university. There were three hundred twenty eight (328) females and one hundred eighty three (183) males.

\section{Instrument}

The instrument prepared by the researchers was a survey questionnaire consisting of two parts. The first part gathered the profile of the students according to the variables used in the study. Family origin was categorized as highlander or lowlander based on the location of family origin. Highlanders are those coming from high elevation regions, while lowlanders are those coming for low elevation regions. The types of residence are categorized as apartment, boarding house or bed space; family owned; relative owned; and university housing or dormitory.

The second part consisted of survey questions that determined the waste management practices of the students. Waste materials are categorized as biodegradable, recyclable or residuals which are waste not categorized under biodegradable or recyclable wastes. The waste management practices include waste segregation and waste disposal practices. The values influencing students waste management practices are also measured.

\section{Procedure}

The questionnaires were distributed to respondents who answered them immediately. They were immediately collected. From the same group of respondents, some were placed in a focus group discussion. This method was used to validate or confirm the data supplied by the students. Before the group discussion, they were grouped according to sex and family origin. Separate 
questions were asked from the student respondents to further elaborate and support responses.

\section{Data Analyses}

The following scale was used to categorize the most frequent type of household waste of students.

\begin{tabular}{lll} 
& Descriptive Equivalence & Symbol Used \\
\hline $\mathbf{2 . 4}-\mathbf{3}$ & Always & A \\
$\mathbf{1 . 7}-\mathbf{2 . 3}$ & Sometimes & So \\
$\mathbf{1 - 1 . 6}$ & Seldom & Se \\
\hline
\end{tabular}

The following Likert scale was used to categorize the most frequent handling practices of household waste by students.

\begin{tabular}{lll} 
& Descriptive Equivalence & Symbol Used \\
\hline $\mathbf{2 . 4 - 3}$ & Always & A \\
$\mathbf{1 . 7}-\mathbf{2 . 3}$ & Sometimes & So \\
$\mathbf{1 - 1 . 6}$ & Seldom & Se \\
\hline
\end{tabular}

The following Likert scale was used to categorize the most frequent household waste disposal practices of students.

\section{Descriptive Equivalence Symbol Used}

\begin{tabular}{lll}
\hline $\mathbf{2 . 4}-\mathbf{3}$ & Always & A \\
$\mathbf{1 . 7}-\mathbf{2 . 3}$ & Sometimes & So \\
$\mathbf{1 - 1 . 6}$ & Seldom & Se \\
\hline
\end{tabular}

Frequency and weighted mean were used to determine the household waste handling and disposal practices of BSU students.

One sample t-test was used to compare the level of handling practices of household wastes and waste disposal practices with the average level. The t-test was used to compare the waste management practices, as well as values observed contributing to waste management practices of students when grouped according to sex and family origin (categorized as highlanders or lowlanders), while ANOVA was used to compare the waste management practices and values observed contributing to waste management practices of students when grouped by type of residence and year level. The Fisher's Least Square Difference was used for the Post Hoc tests. All hypotheses were tested at a 0.05 level of significance. 


\section{Result and Discussion}

\section{Type of Household Waste in Students' Household}

Table 1 presents the type of household waste usually found in the students' residences. The household wastes commonly found were vegetable waste, sanitary napkins/diapers-not among the top rated wastes/paper/tissue and plastic wrappers. These household wastes are shown as "always" found with weighted means of 2.4207, 2.3483 and 2.3366, respectively. On the other hand, sanitary napkins/ diapers, cans and plastic containers appear to be the least generated household wastes of BSU students. In relation to other studies, food/kitchen wastes and plastics were also the commonly generated wastes in a Manila barangay (Bernardo 2008) and in other developing countries (Yoada et al. 2014, Ultra \& Ultra 2013).

Table 1. Type of Household Waste Usually Found in Student Household

\begin{tabular}{|l|c|c|c|c|c|}
\hline \multicolumn{1}{|c|}{ Type of Waste } & Seldom & Sometimes & Always & Weighted Mean & Description \\
\hline Fruit Waste & 13.7 & 55.2 & 31.1 & 2.1742 & So \\
\hline Vegetable Waste & 8 & 41.9 & 50.1 & 2.4207 & A \\
\hline Bottles & 17.8 & 47.7 & 34.4 & 2.1663 & So \\
\hline Plastic Containers & 17.6 & 50.1 & 32.3 & 2.1468 & So \\
\hline Plastic Wrappers & 12.1 & 42.1 & 45.8 & 2.3366 & A \\
\hline Sanitary Napkins/diapers & 37.2 & 47.9 & 14.9 & 1.7769 & So \\
\hline Paper/Tissue & 12.9 & 39.3 & 47.7 & 2.3483 & A \\
\hline Left-over Cooked food & 18.4 & 44.2 & 37.4 & 2.1898 & So \\
\hline Cans & 22.7 & 53 & 24.3 & 2.0157 & So \\
\hline
\end{tabular}

Household Waste Segregation of Students

Table 2 presents how household waste is segregated by students into biodegradable, recyclable or residual. Among the household waste, fruit waste, vegetable waste, and left-over cooked food were considered biodegradable; bottles, plastic containers and cans are considered recyclable; and plastic wrappers, sanitary napkins/diapers and paper/tissue are considered residual or waste categorized as non-biodegradable, and non-recyclable.

Table 2. How Household Waste Are Segregated by Students

\begin{tabular}{|l|c|c|c|c|c|c|}
\hline Type of Waste & Residual & Biodegradable & Recyclable & Others & $\begin{array}{c}\text { Weighted } \\
\text { Mean }\end{array}$ & Description \\
\hline Fruit Waste & 5.1 & 93.7 & 0.6 & 0.6 & 1.9667 & Biodegradable \\
\hline $\begin{array}{l}\text { Vegetable } \\
\text { Waste }\end{array}$ & 4.7 & 94.1 & 0.6 & 0.6 & 1.9706 & Biodegradable \\
\hline Bottles & 4.7 & 0.8 & 94.5 & & 2.8982 & Recyclable \\
\hline $\begin{array}{l}\text { Plastic } \\
\text { Containers }\end{array}$ & 7.6 & 0.6 & 91.6 & 0.2 & 2.8434 & Recyclable \\
\hline Plastic Wrappers & 63.4 & 4.1 & 31.9 & 0.6 & 1.6967 & Residual \\
\hline $\begin{array}{l}\text { Sanitary } \\
\text { Napkins/diapers }\end{array}$ & 81.4 & 17.2 & 0.4 & 1 & 1.2094 & Residual \\
\hline Paper/Tissue & 57.7 & 26.4 & 15.3 & 0.6 & 1.5871 & Residual \\
\hline $\begin{array}{l}\text { Left-over } \\
\text { Cooked food }\end{array}$ & 13.5 & 81 & 0.6 & 4.9 & 1.9687 & Biodegradable \\
\hline Cans & 7.4 & 2.2 & 90.2 & 0.2 & 2.8317 & Recyclable \\
\hline
\end{tabular}




\section{Household Waste Handling Practices of Students}

Table 3 presents the handling practices of household waste of students. Students usually practiced waste segregation, and then placed the waste materials in specified bins or containers. This is shown to be significantly different from the average practice as indicated by the computed t-value of 13.801 which is significant at a 0.01 level of significance. Whereas "all wastes were placed in a waste bin regardless of the type" is only sometimes practiced in the household of students. This result does not differ significantly from the average as shown by the $\mathrm{t}$-value of 0.855 which is not significant at a 0.05 level of significance. The result implies that college students always practice waste segregation at home, as opposed to the findings of Ferrer (2015), and Ehrampoush and Moghadam (2005).

When students are grouped according to sex, female and male students did not differ significantly in handling their household wastes. This is shown by their t-values which are not significant at a 0.05 level of significance. This is further supported through the result of the focus group discussion where both male and female students separated the biodegradable wastes from the nonbiodegradable.

Students, whether coming from family origin of high elevation residence or from low elevation residence, have the same handling practices of household wastes. This is supported by the t-values which are not significant at a 0.05 level of significance. Family origin did not determine waste handling practices of students. A similar result was also found by Vivek et al. (2013) that the type of family origin was not a factor in their waste management practices. Additionally, the focus group discussion revealed that students from both high and low lands segregate the same type of wastes, such as cans, bottles and plastic containers (recyclable) from fruit and vegetable wastes (biodegradable).

Moreover, when students were grouped by year level, students did not differ significantly in the practice of "waste are segregated and placed in a specified waste bin or waste container" but differed significantly in practicing "all wastes are placed in a waste bin regardless of the type". This is indicated by the F value of 3.847 which was significant at a 0.01 level of significance. Based form the post hoc test, the first students had a higher level of non-segregation practice compared to the third year and fourth year students. Similarly, year level was also found to be a factor in the reuse practices of college students (Ferrer 2015). 
Table 3. Household Waste Handling Practices of Students and Comparison by Sex, Family Origin, Year Level and Type of Residence

\begin{tabular}{|c|c|c|c|c|c|c|c|c|}
\hline \multirow[t]{2}{*}{ Handling Practice } & \multirow[t]{2}{*}{$\begin{array}{l}\text { Weighted Mean/ } \\
\text { Des }\end{array}$} & \multirow[t]{2}{*}{ t-value } & \multicolumn{2}{|c|}{ Grouped by Sex } & \multirow[t]{2}{*}{ t-value } & \multicolumn{2}{|c|}{$\begin{array}{c}\text { Grouped by } \\
\text { Family Origin }\end{array}$} & \multirow[t]{2}{*}{ t-value } \\
\hline & & & $\begin{array}{c}\text { Male } \\
\text { Weighted } \\
\text { Mean/Des }\end{array}$ & \begin{tabular}{|c|} 
Female \\
Weighted \\
Mean/Des
\end{tabular} & & $\begin{array}{l}\text { High Land } \\
\text { Weighted } \\
\text { Mean/Des }\end{array}$ & $\begin{array}{l}\text { Low Land } \\
\text { Weighted } \\
\text { Mean/Des }\end{array}$ & \\
\hline $\begin{array}{l}\text { All waste are placed in a waste bin } \\
\text { regardless of the type }\end{array}$ & $2.0274 /$ So & 0.855 & 2.07/So & $2.00 /$ So & -1.017 & 2.03/So & 2.04/So & 0.157 \\
\hline \multirow{3}{*}{$\begin{array}{l}\text { Waste are segregated and placed } \\
\text { in a specified waste bin or waste } \\
\text { container }\end{array}$} & $2.3896 / \mathrm{A}$ & $13.801 * *$ & $2.39 / \mathrm{A}$ & 2.39/So & 0.038 & $2.40 / \mathrm{A}$ & $2.32 /$ So & -1.09 \\
\hline & \multicolumn{7}{|c|}{ Grouped by Year Level } & \\
\hline & $\begin{array}{c}\text { Year 1 } \\
\text { Weighted } \\
\text { Mean/Des }\end{array}$ & $\begin{array}{c}\text { Year } 2 \\
\text { Weighted } \\
\text { Mean/Des }\end{array}$ & \multicolumn{3}{|c|}{$\begin{array}{c}\text { Year } 3 \\
\text { Weighted } \\
\text { Mean/Des }\end{array}$} & \multicolumn{2}{|c|}{$\begin{array}{c}\text { Year } 4 \\
\text { Weighted } \\
\text { Mean/Des }\end{array}$} & $F$ value \\
\hline $\begin{array}{l}\text { All waste are placed in a waste bin } \\
\text { regardless of the type }\end{array}$ & $2.145 /$ So & $2.027 /$ So & \multicolumn{3}{|c|}{$1.86 /$ So } & \multicolumn{2}{|c|}{ 1.95/So } & $3.847 * *$ \\
\hline \multirow{3}{*}{$\begin{array}{l}\text { Waste are segregated and placed } \\
\text { in a specified waste bin or waste } \\
\text { container }\end{array}$} & $2.41 / \mathrm{A}$ & 2.398/A & \multicolumn{3}{|c|}{$2.41 / \mathrm{A}$} & \multirow{2}{*}{\multicolumn{2}{|c|}{$2.32 /$ So }} & 0.473 \\
\hline & \multicolumn{5}{|c|}{ Grouped by Type of Residence } & & & \\
\hline & $\begin{array}{c}\text { Apartment/ } \\
\text { boarding house/ } \\
\text { bed space } \\
\text { Weighted Mean/Des }\end{array}$ & $\begin{array}{c}\text { Family-owned } \\
\text { residence } \\
\text { Weighted } \\
\text { Mean/Des }\end{array}$ & \multicolumn{3}{|c|}{$\begin{array}{l}\text { Relative-owned residence } \\
\text { Weighted Mean/Des }\end{array}$} & \multicolumn{2}{|c|}{$\begin{array}{l}\text { University housing/ } \\
\text { cottage/dormitory } \\
\text { Weighted Mean/Des }\end{array}$} & $F$ value \\
\hline $\begin{array}{l}\text { All waste are placed in a waste bin } \\
\text { regardless of the type }\end{array}$ & 2.0/So & 2.08/So & \multicolumn{3}{|c|}{ 1.99/So } & \multicolumn{2}{|c|}{$2.13 /$ So } & 0.585 \\
\hline $\begin{array}{l}\text { Waste are segregated and placed in } \\
\text { a specified waste bin or waste } \\
\text { container }\end{array}$ & $2.26 /$ So & $2.54 / \mathrm{A}$ & \multicolumn{3}{|c|}{$2.41 / \mathrm{A}$} & \multicolumn{2}{|c|}{$2.67 / \mathrm{A}$} & $7.41 * *$ \\
\hline
\end{tabular}


Though students express that they sometimes do not segregate household wastes, there were more lower-level students than higher-level students who practiced it. This suggests that upper year level students may have integrated in their household the waste management practices being done in the university while lower level students, being new in the university, could still be practicing what they are accustomed to. As corroborated in the focus group discussion, higher year level students mentioned that they learned waste management practices in school.

As for the type of residence, students who live in apartment/boarding house/ bed space do not practice as much of waste segregation and placing them in specified bins or containers as compared to students who live in family-owned residence, in relative-owned residence and in university housing/cottage/ dormitory. This result is based on the post hoc test result and by the F value of 7.41 which is significant at a 0.05 level of significance. This means that the waste handling practices of students depend on their type of residence. One reason could be that students who live in this type of residence gain no economic return if they segregate. Another explanation may be that waste segregation practices are not promoted or are not strictly implemented in boarding houses, apartments or bed spaces. Also from the focus group discussion of the respondents, they mentioned that the reason they do not segregate is lack of knowledge in the barangay or the captain does not care about segregation so the constituents just follow the same attitude.

On the other hand, all of the students, regardless of type of residence sometimes place "all wastes in a waste bin regardless of the type" with an $\mathrm{F}$ value of 0.585 , which is not significant at 0.05 level of significance.

\section{Household Waste Disposal Practices of Students}

Table 4 shows the waste disposal practices of students in their household. Among the listed waste disposal practices "waste disposal through pick up by trucks" is always practiced; "segregate the recyclables then burn the rest" is sometimes practiced, while "burning all types of wastes" and "all wastes placed in a compost pit" are seldom practiced, all significantly different from the average usage as implied by their t-values of $15.647,36.629,-9.01$ and -11.03 , respectively, which are all significant at a 0.05 level of significance.

Female and male students do not differ significantly on how they dispose of waste. The exception to this regards "garbage picked up by hired trucks for disposal" as indicated by the t-value of 6.183 significant at a 0.01 level of significance. Female students dispose of household waste more frequently this way compared to male students.

Furthermore, students coming from high elevation residences and those coming from low elevation residences did not differ significantly on their waste disposal practices except for the use of compost pit as can be seen from the t-value of 2.603 which is significant at a 0.01 level of significance. Compost pit usage, though categorized as sometimes practiced, was done more frequently by students from the low lands than students from the high lands. This could be attributed to the warmer climate in the low lands where the rate of decomposition is faster. In 
addition, in the focus group discussion among the respondents, students from the low lands mentioned that biodegradable wastes are placed in holes and also used as fertilizers.

Students, regardless of year level, seldom burned their waste and/or separated the recyclables then burn the rest. However, there were more students in the lower year level who always have their waste picked up by hired trucks than higher year level students as shown by the $F$ value of 6.183 which is significant at a 0.05 level of significance. Based on post hoc test results, second year students have their waste picked up by hired trucks far more frequently compared to the third year and fourth year students. In addition, students from all year levels differed significantly on the level by which wastes were placed in a compost pit as indicated by the computed $F$ value of 3.255 which is significant at a 0.05 level of significance. The first year students more frequently use a compost pit compared to the third year students who significantly use more of the compost pit compared to the fourth year students.

Waste disposal practices of students depend on the type of residence where they live. Students who lived in apartments/boarding houses/bed spaces did not practice segregating recyclable wastes then burning the rest as much as students who lived in family or relative owned houses and in university housing/cottages/ dormitories. This is shown by the $\mathrm{F}$ value of 4.122 , which is significant at a 0.01 level of significance. Based on post hoc test results, students living in a family owned residence practice more segregating recyclable wastes then burning the rest compared to those living in apartments, boarding houses or bed spaces.

In addition, students in family owned residences always let their garbage be picked up by trucks compared to those leaving in relative owned residences, apartments, boarding houses, bed spaces, university housing or dormitory. This difference is supported by an $\mathrm{F}$ value of 7.422 and post hoc test results, which were significant at a 0.05 level of significance. Also, compost pit usage is sometimes practiced by students living in family owned houses and in university housing/cottages/dormitories, while it is not practiced much by students who live in relative owned houses and in apartments/ boarding houses/bed spaces. The post hoc test and $\mathrm{F}$ value of 3.327 showed these differences to be significant at a 0.05 level of significance. Reasons for the above differences could be location, convenience, or availability of space.

On the other hand, no difference was shown in the burning practice of all types of waste as shown by the $F$ value of 0.227 not significant at a 0.05 level of significance. Regardless of the type of residence where students live, the practice mentioned above is seldom done. It could be that there are no available spaces to burn wastes or students are aware of the "No burning of waste" ordinance. 
Table 4. Household Waste Disposal Practice of Students and Comparison when Grouped according to Sex, Family Origin, Year Level and Type of Residence

\begin{tabular}{|c|c|c|c|c|c|c|c|c|}
\hline \multirow[t]{2}{*}{ Handling Practice } & \multirow{2}{*}{$\begin{array}{l}\text { Weighted } \\
\text { Mean/Des }\end{array}$} & \multirow[t]{2}{*}{ t-value } & \multicolumn{2}{|c|}{ Grouped by Sex } & \multirow{2}{*}{ t-value } & \multicolumn{2}{|c|}{ Grouped by Family Origin } & \multirow[t]{2}{*}{ t-value } \\
\hline & & & $\begin{array}{c}\text { Male } \\
\text { Weighted } \\
\text { Mean/Des }\end{array}$ & $\begin{array}{c}\text { Female } \\
\text { Weighted } \\
\text { Mean/Des }\end{array}$ & & $\begin{array}{c}\text { High Land } \\
\text { Weighted } \\
\text { Mean/Des }\end{array}$ & $\begin{array}{l}\text { Low Land } \\
\text { Weighted } \\
\text { Mean/Des }\end{array}$ & \\
\hline All type of waste are burned & $1.2564 / \mathrm{Se}$ & $36.629 * *$ & $1.26 / \mathrm{Se}$ & $1.26 / \mathrm{Se}$ & -0.017 & $1.25 / \mathrm{Se}$ & $1.30 / \mathrm{Se}$ & 0.953 \\
\hline $\begin{array}{l}\text { Recyclable wastes are segregated } \\
\text { the rest are burnt }\end{array}$ & $1.7182 / \mathrm{So}$ & $-9.01 * *$ & $1.67 / \mathrm{A}$ & $1.74 /$ So & 1.113 & $1.72 /$ So & $1.71 /$ So & -0.104 \\
\hline $\begin{array}{l}\text { Garbage are picked up by trucks for } \\
\text { disposal }\end{array}$ & $2.5108 / \mathrm{A}$ & $15.647 * *$ & 2.39/A & $2.58 / \mathrm{A}$ & $2.701 * *$ & $2.50 / \mathrm{A}$ & $2.57 / \mathrm{A}$ & 0.873 \\
\hline \multirow[t]{3}{*}{ All wastes are placed in a compost pit } & $1.6399 / \mathrm{Se}$ & $-11.03 * *$ & $1.64 / \mathrm{Se}$ & $1.64 / \mathrm{Se}$ & 0.013 & $1.60 / \mathrm{Se}$ & $1.84 /$ So & $2.603 * *$ \\
\hline & \multicolumn{7}{|c|}{$\begin{array}{l}\text { Grouped by Year Level } \\
\end{array}$} & \\
\hline & \multicolumn{2}{|c|}{$\begin{array}{c}\text { Year } 1 \\
\text { Weighted Mean/Des }\end{array}$} & $\begin{array}{c}\text { Year } 2 \\
\text { Weighted Mean/Des } \\
\end{array}$ & \multicolumn{2}{|c|}{$\begin{array}{c}\text { Year } 3 \\
\text { Weighted Mean/Des }\end{array}$} & \multicolumn{2}{|c|}{$\begin{array}{c}\text { Year } 4 \\
\text { Weighted Mean/Des }\end{array}$} & F value \\
\hline All type of waste are burned & \multicolumn{2}{|c|}{$1.28 / \mathrm{Se}$} & $1.24 / \mathrm{Se}$ & \multicolumn{2}{|c|}{$1.22 / \mathrm{Se}$} & \multicolumn{2}{|c|}{$1.27 / \mathrm{Se}$} & 0.498 \\
\hline $\begin{array}{l}\text { Recyclable wastes are segregated } \\
\text { the rest are burnt }\end{array}$ & \multicolumn{2}{|c|}{$1.78 /$ So } & $1.62 / \mathrm{Se}$ & \multicolumn{2}{|c|}{$1.71 /$ So } & \multicolumn{2}{|c|}{ 1.71/So } & 1.279 \\
\hline $\begin{array}{l}\text { Garbage are picked up by trucks for } \\
\text { disposal }\end{array}$ & \multicolumn{2}{|c|}{$2.515 / \mathrm{A}$} & $2.73 / \mathrm{A}$ & \multicolumn{2}{|c|}{$2.34 /$ So } & \multicolumn{2}{|c|}{ 2.39/A } & $6.183 * *$ \\
\hline \multirow[t]{3}{*}{ All wastes are placed in a compost pit } & \multicolumn{2}{|c|}{$1.715 /$ So } & $1.55 / \mathrm{Se}$ & \multicolumn{2}{|c|}{$1.48 / \mathrm{Se}$} & \multicolumn{2}{|c|}{$1.73 / \mathrm{So}$} & $3.255^{* *}$ \\
\hline & \multicolumn{7}{|c|}{ Grouped by Type of Residence } & \\
\hline & \multicolumn{2}{|c|}{$\begin{array}{l}\text { Apartment/boarding } \\
\text { house/bed space } \\
\text { Weighted Mean/Des }\end{array}$} & \begin{tabular}{|c|} 
Family-owned \\
residence \\
Weighted Mean/Des
\end{tabular} & \multicolumn{2}{|c|}{$\begin{array}{c}\text { Relative-owned residence } \\
\text { Weighted Mean/Des }\end{array}$} & \multicolumn{2}{|c|}{$\begin{array}{l}\text { University housing/ } \\
\text { cottage/dormitory } \\
\text { Weighted Mean/Des }\end{array}$} & $F$ value \\
\hline All type of waste are burned & \multicolumn{2}{|c|}{$1.25 / \mathrm{Se}$} & $1.27 / \mathrm{Se}$ & \multicolumn{2}{|c|}{$1.24 / \mathrm{Se}$} & \multicolumn{2}{|c|}{$1.33 / \mathrm{Se}$} & 0.227 \\
\hline $\begin{array}{l}\text { Recyclable wastes are segregated } \\
\text { the rest are burnt }\end{array}$ & \multicolumn{2}{|c|}{$1.62 / \mathrm{Se}$} & $1.84 /$ So & \multicolumn{2}{|c|}{ 1.70/So } & \multicolumn{2}{|c|}{$2.00 /$ So } & $4.122 * *$ \\
\hline $\begin{array}{l}\text { Garbage are picked up by trucks for } \\
\text { disposal }\end{array}$ & \multicolumn{2}{|c|}{$2.60 / \mathrm{A}$} & $2.29 /$ So & 2.6 & & & & $7.422 * *$ \\
\hline All wastes are placed in a compost pit & 1.5 & & $1.73 /$ So & 1.6 & & 2.0 & & $3.327 *$ \\
\hline
\end{tabular}




\section{Student Values Contributing to their Waste Management Practices}

Table 5 presents the values of students contributing to their waste management practices. As seen from the data, student values -such as environmental concern, law or ordinance compliance, personal image in the community, and usefulness of recycled waste- were considered the most frequent reasons for practicing waste segregation. On the other hand, financial gain in recycled waste, penalty, and fear of uncollected waste accumulation were sometimes reasons why waste segregation was being undertaken.

When students were grouped according to sex, both male and female students similarly reported values contributing to their waste management practices as shown by the computed t-values which were not significant at a 0.05 level of significance. Only the value "usefulness of recyclable waste" was gender dependent as indicated by the t-value of 1.987 which was significant at a 0.05 level of significance. Female students could be said to consider recycling of wastes more important than do their male counterparts. This is corroborated by the study of Ifegbesan (2009) that female students showed positive waste management practices compared to male students.

As to family origin, respondents from both high and low lands showed the same values contributing to their waste management practices as shown by the $\mathrm{t}$-values, which were not significant at the 0.05 level of significance. In this study, waste management practices did not depend on where the students come from or their family origin. This result was also true of the findings of Vivek et al. (2013).

Furthermore, students from all year levels also had the same values contributing to their waste management practices except for the value "financial gain in recycled waste". This is based on the computed F values, which were not significant at a 0.05 level of significance while the $F$ value of "financial gain in recycled waste" of 3.831 is significant at a 0.05 level of significance. This implies that the economic value of recycled waste depends on the year level of students. Post hoc test results showed that both freshmen (2.06) and senior students (2.01) find more economic gain in recycling wastes than sophomore and junior college students.

When students are grouped according to the type of residence they have, their value level on "financial gain in recycled waste" and "usefulness of recyclable waste" differ significantly as supported by the Post hoc test result and $F$ values of 4.247 and 2.732, respectively, which were all significant at a 0.05 level of significance. Students leaving in apartments, boarding houses or bed space value less of the financial gain in recycled waste than students in other types of residence. Also, students who resided in family owned residences value the usefulness of recyclable waste more than those living in the other types of residences. 
Table 5. Student Values Contributing to their Waste Management Practices

\begin{tabular}{|c|c|c|c|c|c|c|c|}
\hline \multirow[t]{2}{*}{ Handling Practice } & \multirow{2}{*}{$\begin{array}{l}\text { Weighted Mean/ } \\
\text { Description }\end{array}$} & \multicolumn{2}{|c|}{ Grouped by Sex } & \multirow[t]{2}{*}{ t-value } & \multicolumn{2}{|c|}{ Grouped by Family Origin } & \multirow[t]{2}{*}{ t-value } \\
\hline & & $\begin{array}{c}\text { Male } \\
\text { Weighted } \\
\text { Mean/Des }\end{array}$ & $\begin{array}{c}\text { Female } \\
\text { Weighted } \\
\text { Mean/Des }\end{array}$ & & $\begin{array}{l}\text { High Land } \\
\text { Weighted } \\
\text { Mean/Des }\end{array}$ & $\begin{array}{l}\text { Low Land } \\
\text { Weighted } \\
\text { Mean/Des }\end{array}$ & \\
\hline $\begin{array}{l}\text { Financial gain in recycled } \\
\text { waste }\end{array}$ & $1.9569 / \mathrm{So}$ & 1.92/So & $1.98 /$ So & 0.818 & 1.97/So & 2.04/So & -0.851 \\
\hline $\begin{array}{l}\text { Concern with the } \\
\text { environment }\end{array}$ & $2.6125 / \mathrm{A}$ & $2.58 / \mathrm{A}$ & $2.63 / \mathrm{A}$ & 1.016 & $2.62 / \mathrm{A}$ & $2.55 / \mathrm{A}$ & -1.068 \\
\hline $\begin{array}{l}\text { Usefulness of recyclable } \\
\text { waste }\end{array}$ & $2.4266 / \mathrm{A}$ & $2.36 / \mathrm{A}$ & $2.47 / \mathrm{A}$ & $1.987^{*}$ & $2.43 / \mathrm{A}$ & $2.41 / \mathrm{A}$ & -0.290 \\
\hline $\begin{array}{l}\text { Compliance to } \\
\text { ordinance/law }\end{array}$ & $2.3640 / \mathrm{A}$ & 2.32/So & 2.39/So & 1.094 & $2.37 / \mathrm{A}$ & $2.36 / \mathrm{A}$ & -0.128 \\
\hline Penalty & $2.002 /$ So & 1.97/So & $2.02 / \mathrm{So}$ & 0.606 & $2.00 / \mathrm{So}$ & 2.04/So & 0.434 \\
\hline $\begin{array}{l}\text { Personal image in the } \\
\text { community }\end{array}$ & $2.509 / \mathrm{A}$ & $2.10 /$ So & 2.02/So & -1.165 & $2.06 /$ So & 2.03/So & -0.302 \\
\hline \multirow{3}{*}{$\begin{array}{l}\text { Fear of accumulation of } \\
\text { uncollected } \\
\text { waste because of non- } \\
\text { compliance to waste } \\
\text { segregation }\end{array}$} & 2.0998/So & 2.13/So & 2.09/So & -0.587 & $2.10 /$ So & 2.09/So & -0.078 \\
\hline & \multicolumn{6}{|c|}{ Grouped by Year Level } & \\
\hline & $\begin{array}{c}\text { Year } 1 \\
\text { Weighted Mean/Des }\end{array}$ & $\begin{array}{c}\text { Year 2 } \\
\text { Weighted } \\
\text { Mean/Des }\end{array}$ & \multicolumn{2}{|c|}{$\begin{array}{c}\text { Year } 3 \\
\text { Weighted Mean/Des }\end{array}$} & \multicolumn{2}{|c|}{$\begin{array}{c}\text { Year } 4 \\
\text { Weighted Mean/Des }\end{array}$} & $\mathrm{F}$ value \\
\hline $\begin{array}{l}\text { Financial gain in recycled } \\
\text { waste }\end{array}$ & 2.06/So & $1.81 /$ So & \multicolumn{2}{|c|}{$1.86 / \mathrm{So}$} & \multicolumn{2}{|c|}{$2.01 /$ So } & $3.831 * *$ \\
\hline $\begin{array}{l}\text { Concern with the } \\
\text { environment }\end{array}$ & $2.66 / \mathrm{A}$ & $2.63 / \mathrm{A}$ & \multicolumn{2}{|c|}{$2.62 / \mathrm{A}$} & \multicolumn{2}{|c|}{$2.51 / \mathrm{A}$} & 2.027 \\
\hline $\begin{array}{l}\text { Usefulness of recyclable } \\
\text { waste }\end{array}$ & $2.51 / \mathrm{A}$ & $2.39 / \mathrm{A}$ & \multicolumn{2}{|c|}{ 2.31/So } & \multicolumn{2}{|c|}{$2.21 / \mathrm{A}$} & 2.544 \\
\hline
\end{tabular}


Vol. 5, No. 3

Dolipas et al.: Waste Handling Practices and Values...

\begin{tabular}{|c|c|c|c|c|c|}
\hline $\begin{array}{l}\text { Compliance to } \\
\text { ordinance/law }\end{array}$ & $2.345 / \mathrm{A}$ & $2.37 / \mathrm{A}$ & $2.40 / \mathrm{A}$ & $2.36 / \mathrm{A}$ & 0.150 \\
\hline Penalty & $2.01 /$ So & $2.02 /$ So & $1.96 /$ So & $2.02 /$ So & 0.124 \\
\hline $\begin{array}{l}\text { Personal image in the } \\
\text { community }\end{array}$ & $2.105 /$ So & 2.05/So & 2.08/So & 1.92/So & 1.324 \\
\hline \multirow{3}{*}{$\begin{array}{l}\text { Fear of accumulation of } \\
\text { uncollected waste because } \\
\text { of non-compliance to } \\
\text { waste segregation }\end{array}$} & 2.12/So & 2.04/So & 2.097/So & 2.12/So & 0.295 \\
\hline & \multicolumn{5}{|c|}{ Grouped by Type of Residence } \\
\hline & $\begin{array}{l}\text { Apartment/boarding } \\
\text { house/bed space } \\
\text { Weighted Mean/Des }\end{array}$ & $\begin{array}{c}\text { Family-owned } \\
\text { residence } \\
\text { Weighted } \\
\text { Mean/Des }\end{array}$ & $\begin{array}{l}\text { Relative-owned residence } \\
\text { Weighted Mean/Des }\end{array}$ & $\begin{array}{l}\text { University housing/ } \\
\text { cottage/dormitory } \\
\text { Weighted Mean/Des }\end{array}$ & $F$ value \\
\hline $\begin{array}{l}\text { Financial gain in recycled } \\
\text { waste }\end{array}$ & $1.85 /$ So & $2.03 /$ So & 2.02/So & 2.33/So & $4.247 * *$ \\
\hline $\begin{array}{l}\text { Concern with the } \\
\text { environment }\end{array}$ & $2.62 / \mathrm{A}$ & $2.59 / \mathrm{A}$ & 2.617/A & $2.73 / \mathrm{A}$ & 0.360 \\
\hline $\begin{array}{l}\text { Usefulness of recyclable } \\
\text { waste }\end{array}$ & $2.37 / \mathrm{A}$ & $2.51 / \mathrm{A}$ & $2.38 / \mathrm{A}$ & $2.67 / \mathrm{A}$ & $2.732 *$ \\
\hline $\begin{array}{l}\text { Compliance to } \\
\text { ordinance/law }\end{array}$ & $1.6399 / \mathrm{Se}$ & $-11.03 * *$ & $1.64 / \mathrm{Se}$ & $1.64 / \mathrm{Se}$ & 0.769 \\
\hline Penalty & $2.05 /$ So & $2.04 /$ So & $1.91 /$ So & 1.87/So & 10.794 \\
\hline $\begin{array}{l}\text { Personal image in the } \\
\text { community }\end{array}$ & 2.00/So & 2.08/So & 2.10/So & 2.20/So & 0.722 \\
\hline $\begin{array}{l}\text { Fear of accumulation of } \\
\text { uncollected waste because } \\
\text { of non-compliance to } \\
\text { waste segregation }\end{array}$ & 2.10/So & 2.10/So & 2.16/So & 1.87/So & 0.558 \\
\hline
\end{tabular}




\section{Conclusion}

Based on the results of the study, BSU students commonly generated vegetable wastes, papers/tissues and plastic wrappers in their households. On the other hand, sanitary napkins/diapers, cans and plastic containers appear to be the least generated household wastes. BSU students usually practice waste segregation by classifying their solid wastes and disposed the same to the appropriate waste bins or containers in their households. However, they admitted that they sometimes place their wastes in a waste bin regardless of its type. The study also revealed that BSU students have similar household waste handling practices regardless of their sex and family origin. However, the lower level students practiced non-segregation of household wastes more often when compared to the higher level students. Also, waste segregation is practiced more by BSU students who are residing in the University dormitories compared to those who are residing in apartments/boarding houses.

In general, BSU students correctly segregated household wastes into biodegradable, recyclables and residuals, except for the paper/tissue wastes, which they classified as residuals instead of either biodegradable or recyclable wastes. Also, the study results asserted that some BSU students may still be confused on the proper classifications of household solid wastes. BSU students always disposed of their household wastes through "pick up by trucks", while they sometimes disposed of it by segregating the recyclables and burned the rest and seldom burned or used compost pit for all types of their wastes. In relation to their sex, female students more frequently disposed of their household wastes through "pick up by trucks" compared to their male counterparts. Also, lowlanders frequently disposed of their household wastes by placing all types of wastes in a compost pit compared to the highlanders. In relation to their year level, sophomore and freshmen BSU students frequently practiced waste disposal through "pick up by trucks" and placing all types of wastes in a compost pit, compared to the other year levels. Lastly, the waste disposal practices of BSU students varied significantly according to their type of residence.

BSU students consider their environmental concern, compliance to a law or ordinance, personal image in the community, and usefulness of recycled waste in practicing waste segregation. On the other hand, they sometimes think about their potential gain from recycled waste, or penalties and fear of uncollected waste accumulation as the reasons why they have to properly segregate their household wastes. When grouped according to year level, freshmen and senior students highly consider financial gains from recycled wastes compared to the other year levels. Also, students who are residing in the university dormitories greatly consider financial gains from recycled wastes and usefulness of recyclable wastes compared to the other residences. 


\section{Recommendation}

Based on the conclusion, the study recommended that BSU students be reminded to strictly comply with the waste segregation policy of the LGU in their community and the University. This should especially be applied to the lower year level students who may not yet be fully aware of the waste management program, as well as to those residing in apartment/boarding houses. Likewise, the apartment/boarding house owners may need to be reminded to help in the implementation/monitoring of the waste segregation program of the Local Government Unit in their community.

BSU students may need to be further oriented on the proper classifications of household wastes since the result showed that some BSU students may be still confused as to the proper classifications of household solid wastes. For instance, paper/tissue wastes may not be classified as residual as it may be considered as either recyclable or biodegradable wastes. Other than "pick up by truck", the BSU students may need to be reminded and encouraged to use alternative methods of waste disposal, like using a compost pit, especially for commonly generated household wastes are vegetable wastes and papers/tissues which are biodegradables.

The study recommends the need for the University/government to inculcate among BSU students other possible benefits of waste segregations, like financial gains from recycled wastes. This is especially true for the sophomore/junior students and those who are residing outside the University dormitories. More studies are recommended to validate the results of the present study on a wider scope and to investigate the household solid waste management practices of the other stakeholders in the University as to these practices being followed in the University.

\section{References}

Adeolu AT, Enesi DO, Adeolu MO (2014) Assessment of Secondary School Students' Knowledge, Attitude and Practice towards Waste Management in Ibadan, Oyo State, Nigeria. Journal of Research in Environmental Science and Toxicology 3(5): 66-73.

Arora L, Agarwal S (2011) Knowledge, Attitude and Practices Regarding Waste Management in Selected Hostel Students of University of Rajasthan, Jaipur. International Journal of Chemistry, Environmental and Pharmaceutical Research 2(1): 40-43.

Banga M (2013) Household Knowledge, Attitudes and Practices in Solid Waste Segregation and Recycling: The Case of Urban Kampala. Zambia Social Science Journal 2(1).

Bernardo EC (2008) Solid-Waste Management Practices of Households in Manila, Philippines. Annals of the New York Academy of Sciences 1140: 420-424.

Daniel EE, Ibok E (2013) Solid Waste Disposal Habits of Students in Nigerian Universities: A Case of University of Uyo, Nigeria. IOSR Journal off Environmental Science, Toxicology and Food Technology 5(6): 46-50. 
Ehrampoush MH, Moghadam B (2005) Survey of Knowledge, Attitude and Practice of Yazd University of Medical Sciences Students about Solid Wastes Disposal and Recycling. Iranian Journal of Environmental Health Sciences and Engineering 2(2): 26-30.

Ferrer FD (2015) Students' Waste Management Practices: Association to Demographic Profile. International Journal of Science, Environment and Technology 4(1): 125134.

Ifegbesan A (2009) Exploring secondary school students' understanding and practices of waste management in Ogun State, Nigeria. International Journal of Environmental \& Science Education 5(2): 201-215.

Macawile, J, G. Su (2009) Local Government Officials Perceptions And Attitudes Towards Solid Waste Management In Dasmariñas, Cavite, Philippines https://www. researchgate.net/profile/Glenn_Sia_Su/publication/44003980_LOCAL_GOVER NMENT_OFFICIALS_PERCEPTIONS_AND_ATTITUDES_TOWARDS_SOL ID_WASTE_MANAGEMENT_IN_DASMARINAS_CAVITE_PHILIPPINES/li nks/0a85e533f7158d5125000000.pdf

Ultra CI, Ultra AA (2013) Solid Waste Management Practices of Households in the University of Eastern Philippines. Journal of Energy Technologies and Policy 3(11): Special Issue for International Conference on Energy, Environment and Sustainable Economy (EESE 2013).

Vivek R, Licy CD, Saritha K, Anies TK, Josphina CT (2013). Awareness, Attitude and Practice of School Students towards Household Waste Management. Journal of Environment 2(6): 147-150.

Yoada RM, Chirawurah D, Adongo PB (2014) Domestic waste disposal practice and perceptions of private sector waste management in urban Accra. BMC Public Health 214: 697. 
